Optical Instruments. Proceedings of the 1950 London Conference. 1951. Chapman and Hall, London. Pp. 264. (42s.).

Much of this volume of the proceedings of the London Conference on Optical Instruments in 1950 is of considerable interest to ophthalmologists. The opening address by Sir Thomas Merton stresses the debt owed to optics by science, and, indeed, by civilization as a whole. Several of the numerous papers deal with recent developments in optical instruments from the ophthalmic point of view, the most interesting being those on microscopes, phase microscopy, spectrophotometry, photometry, the new types of optical glasses now available in the United States, and plastic lenses.

\title{
REVIEWED IN Ophthalmic Literature
}

Documenta Ophthalmologica. Vols V and VI. Multiple authorship. 1951. Junk, The Hague. Pp. 585. (72 guilders).

This volume of Documenta Ophthalmologica is made up of the following chapters:

1. Netzhautzysten und zystoide Degeneration der Netzhaut. F. P. Fischer.

2. A case of tritanopy. F. P. Fischer, M. A. Bouman, and J. ten Doesschate.

3. Über den Zuckergehalt der subretinalen Flüssigkeit bei ruptureller Netzhautablösung. F. P. Fischer and R. W. v. Nordheim.

4. "Reefing" of the sclerotic in conjunction with diathermy-coagulation of retinal holes. H. J. M. Weve.

5. Die Polarisation des Himmelslichtes, ihr Sinn und ihre Bedeutung. A. v. TschermakSeyssenegg.

6. Essential shrinking of the conjunctiva in a hereditary affection allied to epidermolysis bullosa. A. Sorsby, J. A. Fraser Roberts, and R. T. Brain.

7. Electrical stimulation of the human eye by means of periodical, rectangular stimuli. M. A. Bouman, J. ten Doesschate, and J. v. d. Velden.

8. Stereopsis. H. M. Burian.

9. Growth pressure and metaplasia of conjunctival and corneal epithelium. J. S. Friedenwald.

10. The terminology of the biomicroscopically visible elimination of aqueous humour. K. W. Ascher.

11. Les "sarcomes" de la choroïde. Leur aspects-leur nature-leur origine. J. Nordmann and A. Brini.

12. Abflussdruck, Minutenvolumen und Widerstand der Kammerwasserströmung des Menschen. H. Goldmann.

13. Über die praktische Bedeutung der Blutdruckmessung an der Zentralarterie der Netzhaut. E. Weigelin and H. K. Müller.

14. Some problems of protein chemistry of the eye. A. J. Schaeffer.

15. Spaltlampenmikroskopie und Ophthalmoskopie am Auge von Ratte und Maus. R. Brückner.

16. Pathogénie du glaucome capsulaire. L. Weekers, R. Weekers, and J. Dedoyard.

17. Das Verhalten von Luft und Gasen in Bindehaut, Hornhaut und Vorderkammer. C. Koch.

Since these papers, all of which are of high standard and of more than usual interest, will be reviewed individually in Ophthalmic Literature it is not proposed to give them further mention here.

Ophthalmic Nursing. By M. H. Whiting. Sixth Edition, 1951. Churchill, London. Pp. 138, 56 figs. (8s. 6d.).

The sixth edition of this work, now accepted as a standard for nurses in Gt. Britain, brings its predecessor up-to-date but without introducing radical changes. It might be well in the future if additions were counter-balanced by deletions-if, for example, the cautery puncture operation were offset by the omission of the thermo-cautery which is probably rarely performed nowadays for retinal detachment. 